\title{
Emas National Park and the plight of the Brazilian cerrados
}

\author{
Kent H. Redford
}

Brazil's Emas National Park protects important populations of the endangered pampas deer, giant anteaters, armadillos, rheas and many other mammals and birds, but its road and river boundaries are not the best that could be provided to protect this valuable cerrado Park. Uncontrolled fires are also a problem, killing giant anteaters and destroying gallery forest. The author spent two years doing research in central Brazil and visited the Park many times.

Brazil has an active national park programme and has displayed great interest in preserving its natural heritage in parks and biological reserves. Approximately 1.0 per cent of the total land area of Brazil is preserved in national parks (Anon., 1982a). However, the different major vegetation types of Brazil are not all adequately represented within these parks. The cerrado (sensu lato) vegetation zone covers approximately $15-25$ per cent of Brazil (estimates vary; see Eiten, 1972), yet only approximately 11 per cent of the land within national parks is cerrado. The one park in which the cerrado is well represented, Emas National Park, should be further enlarged to ensure the conservation of this vegetation type in a national park. The threats to the integrity of Emas Park are symptomatic of the threats to the cerrado as a whole.

The cerrado is Brazil's second largest vegetation formation, covering from one-and-a-half to two million square kilometres (Anon., 1982a). In its broadest sense, cerrado is defined as a xeromorphic semi-deciduous arboreal savanna composed of several distinct subunits (Eiten, 1972). These include (i) campos or open grasslands with 210 no trees or shrubs; (ii) cerrados (sensu stricto), or semi-arboreal scrubland; (iii) cerradão or tall cerrado, characterized by a greater density of trees of higher stature and semi-open canopy; and (iv) gallery forests or narrow strips of tall tropical forest, usually non-deciduous, found along permanent water courses or valleys where the water table is close to the surface.

Emas National Park, which includes the largest amount of cerrado, is situated on the border of Goias and Mato Grosso do Sul States in southwestern Brazil (18 $8^{\circ} 45^{\prime} \mathrm{S}$ and $\left.52^{\circ} 45^{\prime} \mathrm{E}\right)$. It was established in 1961 and named after the rheas Rhea americana abundant within its confines (Anon., 1981). Located on the watershed between the La Plata and Amazon River basins, Emas Park sits on the western edge of the Central Brazilian plateau, just before it degrades into the Pantanal. The Park is drained by two small rivers, the Jacuba and the Formosa, which arise within its boundaries.

Approximately 60 per cent of the Park's 131,868 hectares consist of grassland, most of the rest being cerrado or cerradão. Narrow strips of gallery forest edge the rivers, and grassy swamps with Mauritia palms mark the beginnings of several small streams which feed these rivers. The Jacuba River runs for a considerable distance through an open flood plain with only patches of bordering forest. This forest undoubtedly extended further before the arrival of farmers and ranchers. The forest at the source of the Jacuba is one of the only pieces of dry forest in the Park. Virtually all of the other gallery forest stands on inundated ground, the forest itself being bordered by a narrow strip of perpetually inundated Oryx Vol 19 No 4 
grassland. Large, open areas of swampy grassland exist in two areas in the Park.

Approximately $1500 \mathrm{~mm}$ of rain falls during the September to May wet season (Anon., 1981). During the rest of the year, virtually no rain falls and the temperature can exceed $35^{\circ} \mathrm{C}$ during the day. At night it can be cold, and every few years the Park experiences a frost that kills most of the foliage.

Very little research has been done in Emas and it has only rarely been visited by non-Brazilians. Several teams have conducted brief surveys within the Park (Nogueira et al., 1978; Pereira et al., 1981; Schaller and Duplaix-Hall, 1975), and Erize (1977) reported on Emas in this journal. This situation is typical not only of Emas but of the whole cerrado region, as most researchers who have gone to Brazil have worked only in Amazonia.

Emas Park has been called 'Brazil's finest national park' (Erize, 1977), and all who have visited it remark on the ease with which wildlife can be observed. The mammalian fauna is typical of the cerrado zone, with many species relying on the

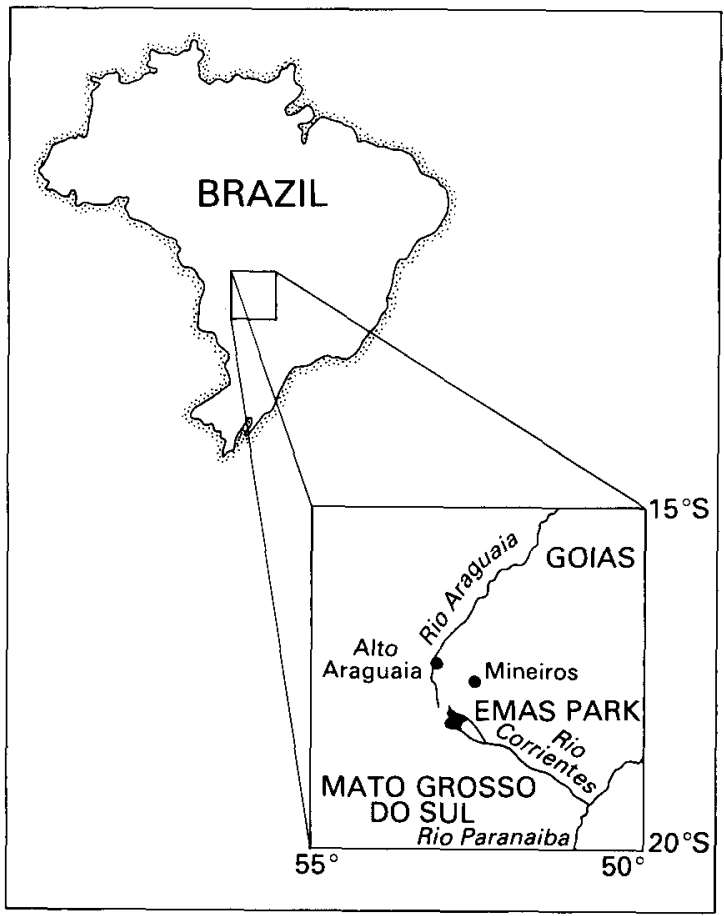

Location of Emas Park (from Anon., 1981).

Emas National Park and the Brazilian cerrados

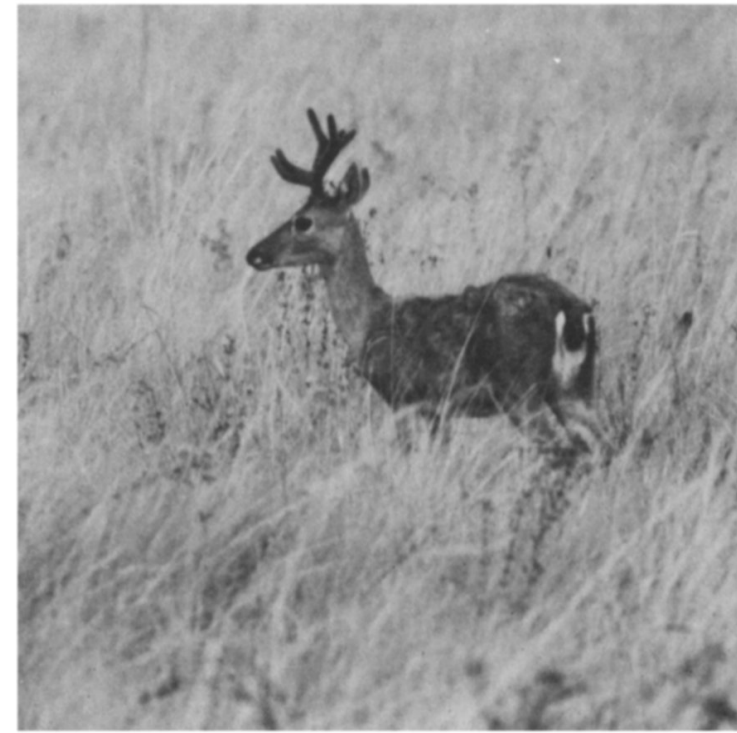

Pampas deer stag with antlers in velvet (Kent H. Redford).

gallery forest for food, water and shelter (Redford, 1983; Redford and Fonseca, 1985). Small groups of the endangered pampas deer Ozotoceros bezoarticus are common in the Park (Redford, in press) and represent the only sizeable populations of this species protected in any national park. Emas also contains a good population of giant anteaters Myrmecophaga tridactyla. These lumbering creatures are commonly seen in and around the Park. At least seven armadillo and anteater species are found in Emas, along with tapirs, two species of peccaries, marsh deer Blastoceros dichotomus and 14 species of carnivores including maned wolves Chrysocyon brachyurus, bush dogs Speothos venaticus, jaguars Panthera onca and two otter species. Surveys of population size and habit requirements are urgently needed, for many of these are endangered species. A thorough mammal survey úsing live-traps and mist-nets is also needed as the Park probably contains many unrecorded species of mammals such as the fascinating fossorial echymid rodents Clyomys and Carterodon.

Emas Park supports a rich and diverse avifauna. R. Ridgley (pers. comm.) has recorded at least 185 species during the dry season, and $P$. Antas (pers. comm.) reports that migratory birds such as roseate spoonbills Ajaia ajaja arrive during the 


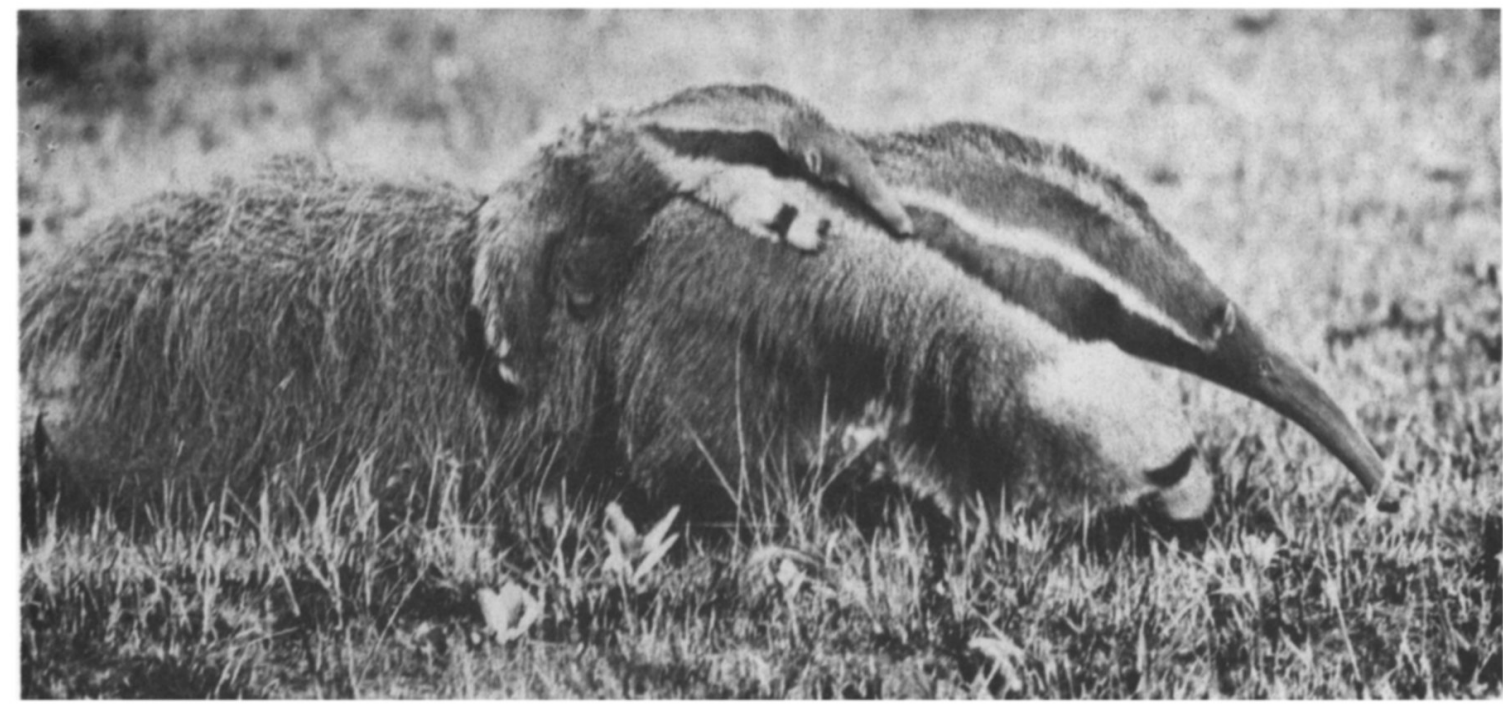

Giant anteater with young (Kent H. Redford).

wet season. The most commonly seen birds include rheas Rhea americana, seriamas Cariama cristata, grey monjitas Xolmis cinerea, and redwinged tinamous Rhynchotus rufescens. Rare species include the dwarf tinamou Taoniscus nanus and the white-winged nightjar Caprimulgus candicans, while the first Brazilian record of the rufous-rumped seedeater Sporophila hypochroma was made in the Park (R. Ridgley, unpubl.). As with the mammals, many of the bird species rely on the gallery forest and would be extirpated if this habitat were destroyed (Redford and Fonseca, 1985).

Perhaps the most impressive element of the fauna are the social insects. Termite mounds dominate the open vegetation formations: there are an estimated 25 million termitaria in the grassland of Emas Park (Redford, 1984). The tall mounds of Comitermes cumulans house nesting birds, provide shelter for many kinds of mammals, reptiles and invertebrates, and are used as domiciles by many species of ants and other termites. They assume the role of trees in the open campos. C. cumulans mounds also host the larvae of a species of Pyrearinus beetle, which provides one of the most impressive of Emas's sights. For a few weeks at the beginning of the wet season, during early evening, the landscape is transformed into a city of lights as millions of these 212 larvae produce a faint yellow-blue light (Redford, 1982).

With its expanses of grassland and cerrado cut by lush gallery forest and its rich fauna, Emas National Park is unique in South America. It contains the largest expanse of conserved cerrado in Brazil and rich concentrations of the cerrado fauna. However, the richness contained in the Park is not safe due to two major factors: inappropriate boundaries and fire (Erize, 1977; Schaller and Duplaix-Hall, 1975; Redford, 1981). When Emas Park was formed, the surrounding land was used for low-density cattle grazing and was virtually untouched. Now (1981), two sides of the Park abut on soybean fields and a third on a heavily grazed ranch. Empty insecticide and herbicide tins have been found piled against the boundary fence, and runoff from the fields carries agricultural chemicals. Even though the decree creating Emas stipulated that the sources of the rivers entering the Park were to be protected (Erize, 1977), a number of streams that flow into the Park arise in unprotected springs located outside the Park and the Jacuba River serves as a Park boundary. Much of the gallery forest along the Jacuba River has been cut, decreasing important habitat for many species. The entire Park watershed needs protecting before it becomes further polluted;

Oryx Vol 19 No 4 
watercourses do not make appropriate boundaries for parks. The other inappropriate boundaries are roads; two heavily travelled dirt roads serve as park boundaries. Despite an excellent fence, poachers and casual hunters frequently enter the Park from the roads.

The second major threat to Emas Park is fire. Uncontrolled fires set outside the Park enter and burn virtually the whole area every several years. In 1980, a total of at least six separate fires burned 90 per cent of the Park. Most of these fires are set outside the Park by ranchers to improve grazing quality and to control cattle parasites. Grazing still occurs in some areas of the Park (as of 1981) and some of the fires were probably set within the boundaries. Uncontrolled fires, such as those set by ranchers, kill giant anteaters, and eat into and eventually destroy the gallery forest. Giant anteaters are particularly susceptible to fire because of their long, flammable hair and their inability to flee. After one severe fire, five anteaters were found burned to death (G. Schuerholz, pers. comm.).

There are, however, some advantages to limited fires. In unburned areas, grass can reach 2.5 metres in height, creating a habitat unsuitable for most of the fauna. Fire burns this tall grass and promotes sprouting, creating a habitat favoured by pampas deer, rheas and many other species. Burning and perhaps also grazing seem to increase the density of termites and may prove an

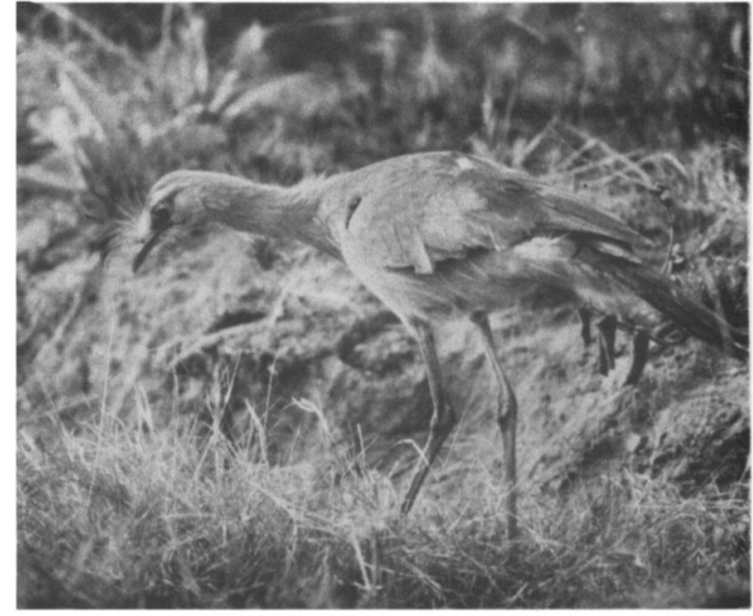

Seriama foraging (Kent H. Redford).

effective tool for managing habitat for giant anteaters and armadillos. In addition, fires are a natural phenomenon in the cerrado, and complete elimination of them would undoubtedly have deleterious consequences. Controlled burning will clearly be an important management tool in Emas Park, but stringent efforts must be made to keep uncontrolled fires from entering and continuing to erode the gallery forests.

The open vegetation formations of South America are rapidly disappearing or becoming unrecognizable under a blanket of rice and livestock pasture. The pampas of Uruguay and

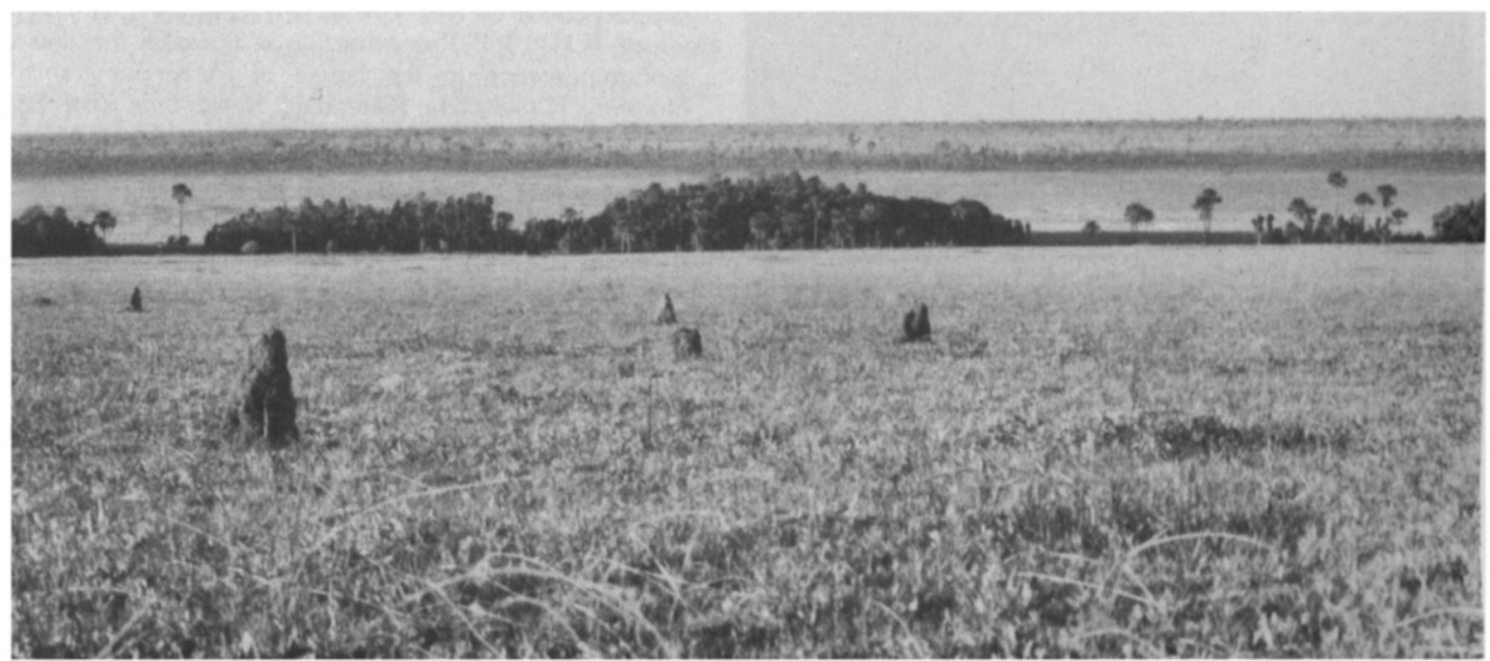

Gallery forest, with gaps probably caused by burning, and termite mounds (Kent H. Redford). 


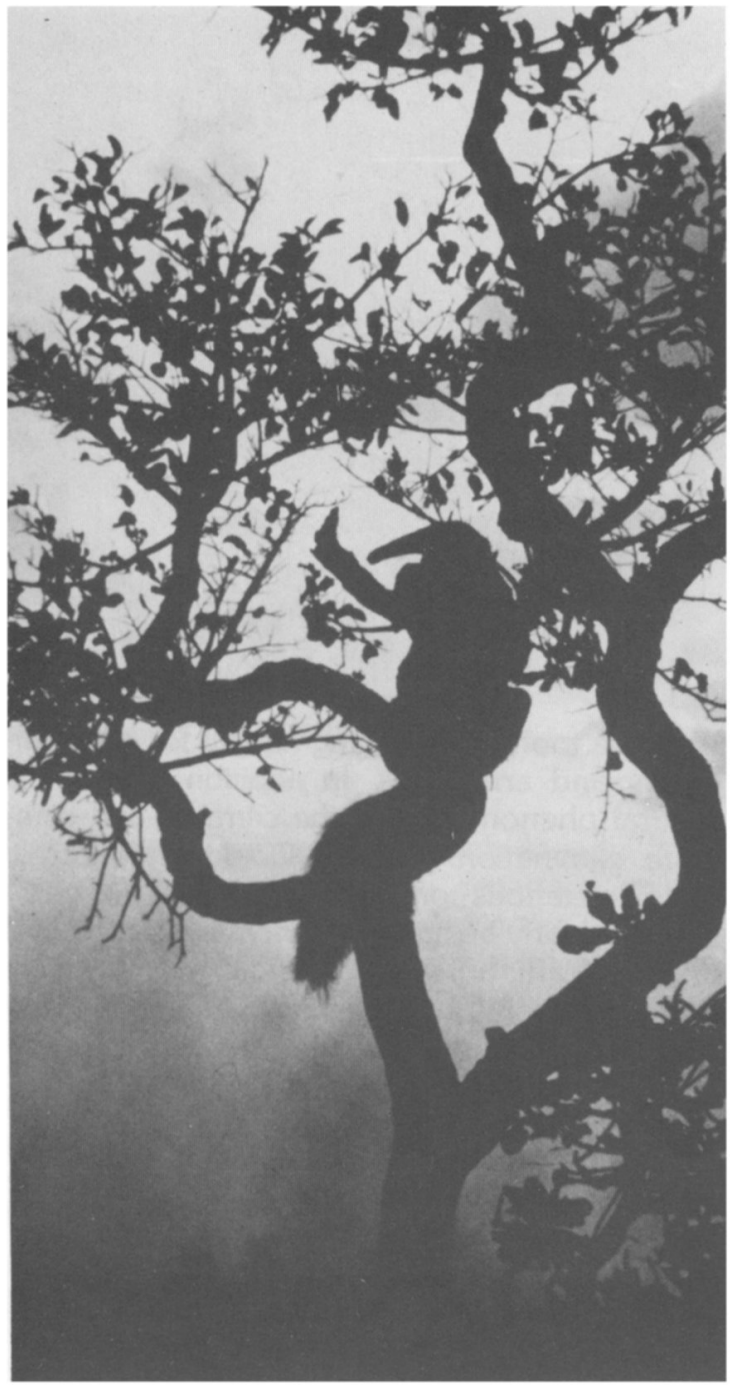

Giant anteater forced up a tree by fire (by courtesy of IBDF).

Argentina have all but disappeared, the llanos of Colombia and Venezuela are under severe pressure, and the cerrado is next. Many have called for the extensive agricultural development of this area (Goodland and Irwin, 1976), and the Brazilian Government is actively encouraging agricultural, livestock and silvicultural development in the cerrado (Anon., n.d.). Emas Park represents the only good piece of cerrado habitat in a national park and even its integrity is threatened. It is important to conserve more cerrado before it too disappears under soybeans and eucalyptus. Our concern for the plight of the 214
Amazonian forest should not blind us to the plight of other endangerd South American habitats.

\section{Acknowledgments}

I would like to thank the Brazilian Institute for Forestry Development (IBDF) for permission to work in Emas Park, and the Park's Director, Heber. Silva de Oliveira, for assistance. Dr Renato Petry Leal generously gave me permission to use photographs from the IBDF files. Financial support for my reserach was provided by the Organization of American States, National Geographic Society, Sigma Xi. Harvard University and Friends of the National Zoo.

\section{References}

Anon. n.d. Cerrado, Terra Para Agricultura. Embrapa.

Anon. 1981. Plano de Manejo. Parque Nacional das Emas. Doct. tec. No. 4, MA IBDF and FBCN

Anon. 1982a. Plano do Sistema de Unidades de Conservação do Brasil. MA IBDF and FBCN.

Anon. 1982b. Anuario Estatistico do Brasil. Fund. Inst. Bras. Geogr. Estat., Rio de Janeiro.

Eiten, G. 1972. The cerrado vegetation of Brazil. Bot. Rev. 38, 201-341

Erize, F. 1977. Brazil's Finest National Park. Oryx, 13, 457462.

Goodland, A.J. and Irwin. H.S. 1976. Amazonian forest and cerrado: development and environmental conservation. In Extinction is Forever (Eds G. T. Prance and T. S. Elias). New York Botanical Gardens, Bronx, New York.

Nogueira, E., Braga, M.A., Estel de Figueiredo, M., Medina Arrais, M.G. and Viana, R.B. 1978. Levantamento geoecologico e cultural no Parque Nacional das Emas. Univ. catolica de Goias, Goiania (unpublished).

Pereira, S.M., Schuerholz, G. and Bastos, E.K. 1981. Parque Nacional das Emas. Apendice ao plano de Manejo (Trabalho de Campo).

Redford, K.H. 1981. Final report to IBDF on research conducted in Brazil from March 1980 to October 1981 (unpublished).

Redford, K.H. 1982. Prey attraction as a possible function of bioluminescence in the larvae of Pyrearinus termitilluminans (Coleoptera: Elateridae). Revta. bras. Zool. São Paulo, 1, 31-34

Redford, K.H. 1983. Lista preliminar de mamíferos do Parque Nacional das Emas. Brasil Florestal, 55, 29-33.

Redford, K.H. 1984. The termitaria of Comitermes cumulans (Isoptera, Termitidae) and their role in determining a potential keystone species. Biotropica, 16, 112-119.

Redford, K.H. in press. The pampas deer (Ozotoceros bezoarticus) in Central Brazil. In The biology of the Cervidae (Ed. C. Wenner). Smithsonian Institution Press, Washington, D.C

Redford, K.H. and Fonseca, G.A.B. 1985. Zoogeography of the cerrado mammalian fauna and the role of gallery forests. Biotropica.

Schaller, G.B. and Duplaix-Hall, N. 1975. Notes on the large mammals of Parque Nacional das Emas, Brazil. (unpublished).

Kent H. Redford, Florida State Museum, University of Florida, Gainesville, FL 32611, USA.

Oryx Vol 19 No 4 